\title{
Fish-habitat associations and the role of disturbance in surfgrass beds
}

\author{
Carey J. Galst*, Todd W. Anderson \\ Department of Biology, San Diego State University, 5500 Campanile Drive, San Diego, California 92182, USA
}

\begin{abstract}
Although there are many studies of fauna associated with seagrass beds in sheltered embayments and estuaries, few have explored such associations in open coastal environments. We determined species richness and documented recruitment and the relative abundance of older life stages of conspicuous, non-cryptic fishes in subtidal surfgrass Phyllospadix torreyi beds in San Diego County, California, USA. Using underwater visual surveys, we explored the relationships between several habitat attributes and the densities of fishes. We then tested experimentally the effects of disturbance (removal of surfgrass) on the densities of fishes. Standardized to the number of individuals encountered, species richness increased with increasing bed area. Expectedly, the variables that explained variation in the density of fishes were species specific. After removal of surfgrass from one-half of the area of disturbed reefs, densities of recruits generally were significantly higher on the undisturbed versus disturbed halves of the reefs, while the densities of older life stages were unaffected. Recruitment in relation to surfgrass area revealed a significant interaction between unmanipulated and disturbed reefs, with a decreasing trend in density on unmanipulated reefs and an increasing trend on disturbed reefs. Our results indicate that surfgrass beds serve as an important habitat for near-shore fishes, and the loss of surfgrass from disturbance has negative consequences for recruitment success.
\end{abstract}

KEY WORDS: Fishes - Surfgrass · Disturbance - Habitat loss · Recruitment - Phyllospadix torreyi · Seagrass Resale or republication not permitted without written consent of the publisher

\section{INTRODUCTION}

Numerous studies have described the relationships between organisms and the structural complexity of their habitats (Lindenmayer \& Hobbs 2004, Bostrom et al. 2006). In marine ecosystems, habitat associations are commonly described for the early life stages of fishes (Carr 1991, Sale et al. 2005) and invertebrates (Eggleston et al. 1998) for some period of time after their transition (settlement) from a pelagic to benthic existence (defined as recruitment; Caley et al. 1996). Because recruitment is thought to be a critical phase in the population dynamics of marine fishes (e.g. Caley et al. 1996, Hixon \& Webster 2002), variation in structural habitat complexity that influences recruitment success has received considerable attention (Carr 1994, Holbrook et al. 2002a). Habitat architecture may be especially important in providing a refuge from predators (Anderson 2001, Johnson 2006), enhancing survival (Rooker et al. 1998) and influencing densitydependent mortality (Hixon \& Webster 2002).

Fish-habitat associations are often species specific, and habitat attributes may play an important role in structuring fish assemblages in various ecosystems (Carr 1991, 1994, Holbrook et al. 2002a, Graham 2004, Nagelkerken \& van der Velde 2004, Bloomfield \& Gillanders 2005). The amount and complexity of habitat, however, does not necessarily enhance recruitment success (Jenkins et al. 1998, Almany 2004), and describing relationships among fauna and ecosystems can be complex (Bell \& Westoby 1986, Sale et al. 2005). Therefore, associations between fishes and habitats merit further investigation, especially in ecosystems in which information on these associations is lacking.

Seagrasses occur in shallow coastal areas worldwide (Bostrom et al. 2006), serving as nursery grounds for fishes and invertebrates (Turner \& Lucas 1985, Heck et al. 2003) and are thought to maintain populations of 
commercially exploited species (Jackson et al. 2001). In particular, the importance of eelgrasses Zostera spp. on faunal abundance and diversity have been widely studied in bays and estuaries (Jackson et al. 2001, Fahrig 2003, Heck et al. 2003, Bostrom et al. 2006). Recruitment often depends on specific habitat attributes such as shoot density and height (Bell \& Westoby 1986), patch size and configuration (Eggleston et al. 1998), and physical processes (Brown et al. 2005).

Several attributes of structural habitat complexity may influence variation in the abundance of organisms in seagrass beds. Patch size and the perimeter or 'edge' of this habitat are important factors in determining the abundance and survival of organisms in seagrass communities (Eggleston et al. 1998, Laurel et al. 2003). The percentage cover of seagrass and the density and height of shoots may also influence the density of fishes and invertebrates (Bell \& Westoby 1986, Webster et al. 1998). The presence of epiphytes, shown to increase food availability in seagrass beds, can influence the abundance of predatory fishes (Bologna \& Heck 1999), and there are distinct differences in the abundance and assemblage structure of fishes among different substratum types (Nagelkerken \& van der Velde 2004, Bloomfield \& Gillanders 2005).

Despite the many studies of seagrasses and their associated fauna, few have been conducted in open coastal environments in which surfgrasses Phyllospadix spp. predominate (Williams 1995, Holbrook et al. 2000, Bull et al. 2004, Menge et al. 2005). Surfgrass communities generally have been studied intertidally (Dethier 1984, Turner \& Lucas 1985, Holbrook et al. 2000, Menge et al. 2005) and, to our knowledge, only one study has documented the fauna associated with surfgrass beds subtidally (conspicuous, non-cryptic fishes; DeMartini 1981). What has not been described, however, is a measure of assemblage structure and the specific relationships between habitat attributes and the abundance of fishes.

Because of their close proximity to the shore, seagrass beds are extremely susceptible to natural (Holbrook et al. 2002b, Moran et al. 2003) and anthropogenic (Bell et al. 2002) disturbances that result in thinning, fragmentation, and habitat loss. Surfgrasses are subject to high wave energy from storms and large swells (Holbrook et al. 2002b, Bull et al. 2004) that may result in their removal; in some instances, much of an entire bed may be lost (e.g. Bull et al. 2004, Menge et al. 2005). Sources of anthropogenic disturbance include offshore oil production (Exxon Company USA 1993) and possibly sedimentation from coastal development. Because surfgrass beds are categorized as 'Essential Fish Habitat' (Sustainable Fisheries [Manguson-Stevens] Act of 1996, 16 U.S.C. $\S 1802$ 2007), developing a better understanding of the associations between fishes and surfgrasses and the impacts of disturbance is necessary.
The goals of the present study were to characterize the non-cryptic fish assemblage in surfgrass beds, determine recruitment and the density of older life stages of these fishes, and examine the relationships between fishes and habitat structure. For the purposes of this study, recruits were individuals that settled during spring and summer of a given year and were censused within a maximum period of 6 mo after settlement. Specifically, we addressed the following questions: (1) What attributes of the structural complexity of surfgrass are important in recruitment, abundance, and the assemblage structure of fishes? (2) Does the loss of surfgrass caused by disturbance affect these patterns?

\section{MATERIALS AND METHODS}

Study sites. We selected 3 sites to evaluate fishhabitat associations in surfgrass beds within San Diego County, California: Bird Rock, Wipeout Beach, and La Jolla Caves (Fig. 1). Sites were selected based on the presence of surfgrass beds, including beds on lowlying bedrock and narrow beds positioned on rocky benches. All beds appeared to consist entirely of Phyllospadix torreyi, although the range of $P$. scouleri also includes southern California. All surfgrass beds remained submerged during tidal flux at 3 to $5 \mathrm{~m}$ depth. Within each site, we selected surfgrass beds that were

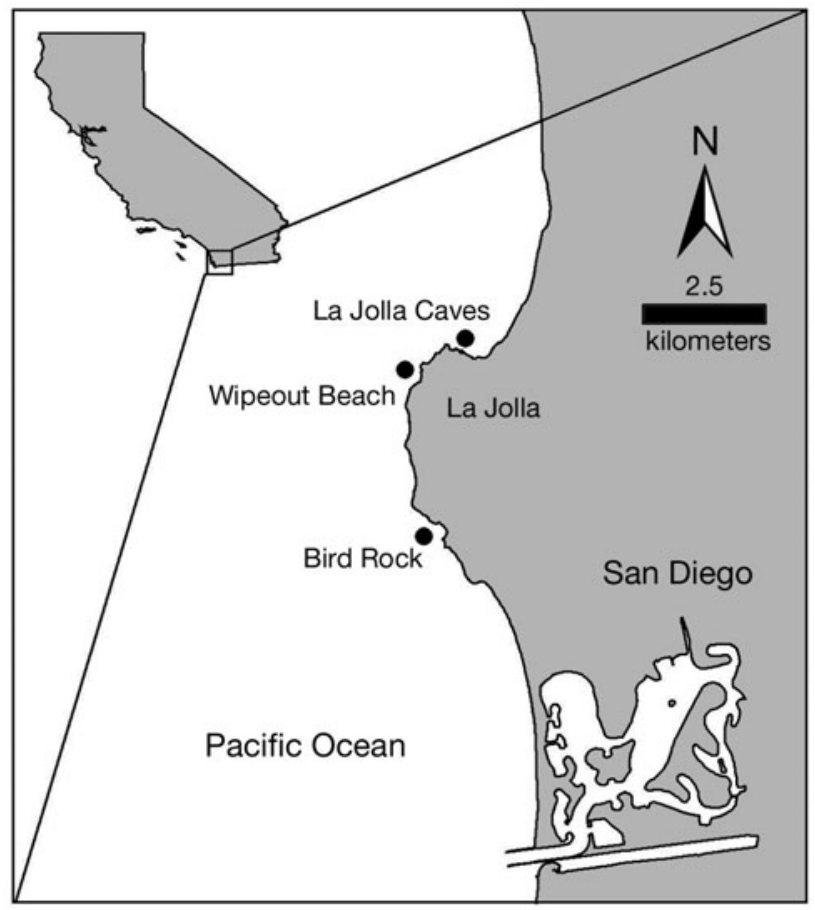

Fig. 1. The 3 study sites in San Diego County, California, USA 
surrounded by sand for at least $10 \mathrm{~m}$ distance from other beds or rocky habitat. Individual beds were marked underwater with rebar stakes and numbered flagging tape, and GPS coordinates were also used to mark their locations.

Characterizing fish assemblages and habitat. Within all sites surfgrass occurred on low-lying bedrock or sand and narrower raised rocky benches. Both types of beds were common at all sites, but we focused on the beds that occurred on raised rocky benches because they were amenable to experimental manipulation.

Previous studies conducted on fishes in seagrass systems have usually employed throw traps, suction samples, or seines for estimating density. However, these methods are impractical in open-coast, high-energy environments. Moreover, underwater horizontal visibility of at least 3 to $4 \mathrm{~m}$ was often achieved in coastal surfgrass beds during the summer and fall (DeMartini 1981), and we surveyed conspicuous, non-cryptic fishes using SCUBA and visual census techniques. Most of the fishes quantified in the present study occur just above the tallest portion of the surfgrass (C. Galst pers. obs.), allowing visual census to be a reliable and precise method of estimating density as in other rocky reef habitats (DeMartini \& Roberts 1982, Davis \& Anderson 1989). Occasionally, fishes were observed fleeing into the surfgrass upon arrival of divers. However, more often we observed them swimming from and above the surfgrass, providing reliable estimates of their densities. Additionally, we did not estimate the densities of cryptic species within surfgrass beds, but only noted them when observed. During our characterizations of surfgrass habitat, we observed few individuals of cryptic species, and those that we did observe (Gobiidae and Blenniidae) appeared to be more closely associated with the rocky reef than with the actual structure of the surfgrass per se. Unlike seagrasses in sheltered bays and estuaries where cryptic fishes are abundant (Bloomfield \& Gillanders 2005, Pihl et al. 2006), surfgrass has densely packed rhizomes which provide only small interstitial spaces as habitat.

Surveys of fishes were conducted by slowly swimming along a transect and recording the number and size (mm total length) of fishes. Depending on bed size, we surveyed between 3 and $150 \mathrm{~m}^{2}$ during each observation period. The number and size of fishes were recorded while deploying a single transect bisecting the bed along its longest dimension. For older juvenile and adult fishes in 2005, we used a $2 \mathrm{~m}$ high by $2 \mathrm{~m}$ wide by variable length transect, depending on the longest dimension (1.7 to $75 \mathrm{~m}$ ). For recording the number of recruits on separate surveys in 2006, we used $1 \mathrm{~m}$ high by $1 \mathrm{~m}$ wide transects by the same variable length of a bed (9 to $75 \mathrm{~m}$ ). There were slight differences in bed lengths between years, because some beds were used for disturbance experiments in 2006 (see following subsection).

Surveys of older juvenile and adult fishes were conducted once per month from July to November 2005. Recruitment was negligible in 2005, so surveys of recruits were conducted from July to October 2006, the period of recruitment of many near-shore temperate fishes in California (Stephens et al. 2006). These monthly estimates were then averaged across months to provide overall estimates of species richness and the abundance of fishes for each bed. For all surveys, we noted, but did not estimate, the density of small cryptic fishes (e.g. sculpins [Cottidae], gobies [Gobiidae]).

We measured the area and perimeter of surfgrass beds and other habitat attributes within $1 \mathrm{~m}^{2}$ quadrats at randomly selected positions along the same transects used to record fishes. Habitat attributes were quantified in July and August 2005 and again in August 2006. Depending on bed area, we sampled from 1 to 15 quadrats in each bed to characterize habitat attributes. The area of each surfgrass bed was calculated from the maximum bed length and several measurements of width along a bed, using the measurements of width as sides of 'triangles' and distance between width measurements as the length. All triangles were then summed to determine the total bed area. The perimeter of each bed was calculated using the average width and longest length to approximate a rectangular shape. Within $1 \mathrm{~m}^{2}$ quadrats, the percentage cover of the substratum covered by surfgrass shoots was determined by lifting surfgrass blades and visually estimating the cover of shoots attached to the substratum. The density of shoots and mean shoot height were estimated by counting all shoots and visually estimating the average shoot height to the nearest centimeter in $25 \mathrm{~cm}^{2}$ quadrats positioned haphazardly within each $1 \mathrm{~m}^{2}$ quadrat. To assess vertical relief, we measured the distance between the top of the substratum at the edge of a seagrass bed to the sand substratum adjacent to the bed at each randomly selected position along a transect. The presence of epiphytes was recorded in the same quadrats used to estimate the density and height of shoots. Blades of surfgrass in each quadrat were inspected to determine the relative amount of epiphytic (encrusting coralline and filamentous red algae) cover. For ease of sampling, we used a categorical measure, ranging from no (-) and moderate $(+)$ epiphytic growth to heavy cover $(++)$, with most blades being covered with epiphytes. Finally, we recorded the type of hard substratum at each randomly selected position along each transect. Substratum categories included sand, bedrock, and cobble.

Effects of habitat disturbance on fish abundance and richness. Narrow surfgrass beds on raised rocky benches were very common at most locations in San 
Diego County. Because these beds were prevalent and relatively isolated from other surfgrass beds, they were amenable to experimental manipulation in simulating natural disturbance. We paired beds of similar size at 3 sites and randomly assigned one as a disturbance treatment and the other as an unmanipulated control. Hereafter, we refer to 2 different types of 'reefs': disturbed reefs were composed of one-half surfgrass and one-half rocky habitat and unmanipulated (control) reefs were covered by surfgrass and were not manipulated in any way. For each disturbed reef, 50 \% cover of seagrass ( 7 to $180 \mathrm{~m}^{2}$ ) was removed by first dividing the reef in half and randomly selecting the half of the reef in which to remove surfgrass. We removed surfgrass (from 26 April to 13 May 2006) by hand to ensure the removal of rhizomes and any vegetation. Permission to remove surfgrass from these reefs was granted by the California Department of Fish and Game (Permit No. 005487).

We surveyed older life stages of fishes and recruits with the same methods and transect dimensions used in characterizing fish assemblages in surfgrass beds. On disturbed reefs, we recorded the location of fishes as to whether they were observed over disturbed or undisturbed habitat. Surveys over several months were conducted at each bed from July to October 2006 to provide estimates of the abundance of fishes, and these estimates were averaged for each bed across months.

Analyses. Species richness was assessed using rarefaction curves. Diversity indices were not used for the following reasons: (1) rarefaction provides results as an easily interpretable value for the expected number of species; (2) a graphical representation is able to be used to compare curves of different habitats, or in this case, surfgrass beds; and (3), most importantly, when data are from areas of differing size, rarefaction can be used to compare communities in terms of density (Neigel 2003). Because bed size varied at our sites, we plotted rarefaction curves of the number of individuals encountered over all consecutive surveys and the estimated cumulative species richness for each surfgrass bed (Dexter 1990, also see Timms 1998 for a similar analysis). To compare species richness among beds of varying size, we used correlation analysis to determine whether a relationship existed between bed size and the estimated species richness for a given number of individuals (Timms 1998). Because species richness generally increases with area sampled or individuals in a collection, this particular technique allows for a comparison of species at a common collection size (Hurlbert 1971). Numbers of species and bed area measures were $\log _{10}$-transformed to meet the assumption of normality for correlation analysis.
To examine the relationship between habitat attributes and the density of both recruit and older fishes, we performed backwards stepwise multiple regression using mean values of each habitat attribute for each surfgrass bed sampled at all 4 sites. To determine the relative importance of all predictor variables remaining in our 'best' model from the backwards stepwise regression, we systematically found the strongest univariate predictor (highest $\mathrm{r}^{2}$ ), then the best 2-variable model, and a 3-variable model as necessary. The partial $r^{2}$ contribution of a variable is the amount of added model explanatory power when that variable is added to the model with the previous variable already in the model. The overall, or 'best', model $\mathrm{r}^{2}$ was then obtained with its corresponding model p-value. For older fishes, we estimated their density and measured habitat attributes at a total of 19 surfgrass beds in 2005. Because recruitment of fishes was negligible in 2005, we estimated the density of recruits and measured habitat attributes at 9 surfgrass beds (other beds were used for simulating habitat disturbance; see 'Results') in 2006. Simple correlation and principle components analysis (PCA) determined if habitat attributes were correlated. For correlated variables, PC factors of combined attributes were used for further analysis instead of individual attributes, to avoid multicollinearity among variables. Attributes of surfgrass beds were the independent variables in the regression models, with the density of fishes as the dependent variable. Separate analyses were performed for both recruit and older fishes.

Analysis of covariance (ANCOVA) was used to test for differences in density between disturbed and unmanipulated reefs, using total reef area as a covariate. ANCOVA was also used to test for differences between disturbance treatments and density, but using only the total area occupied by surfgrass as a covariate. This particular analysis was used to determine if fishes displayed similar relationships on disturbed and unmanipulated reefs when the area of the disturbed rocky reef is ignored; if rocky habitat is unimportant, then we would expect no difference in the relationship between surfgrass area and density between treatments. Residuals were inspected visually to ensure that there were no deviations from normality, and heterogeneity of variances was tested using Cochran's $C$-test. When there were differences in normality or there were heterogeneous variances, data were $\log _{10^{-}}$ transformed to meet the assumptions of ANCOVA. Paired $t$-tests were used to test for differences in the density of fishes on disturbed and undisturbed sides of manipulated reefs only. Densities of total recruits and individual species were $\log _{10}$-transformed to meet assumptions of normality for these tests. All analyses were conducted using SYSTAT (Ver. 11.00.01). 
Table 1. Habitat attributes at 3 sites in San Diego County surfgrass beds. Average value \pm SD for each individual bed. Area sampled: area covered during an older juvenile and adult fish survey

\begin{tabular}{|c|c|c|c|c|c|c|c|}
\hline $\begin{array}{l}\text { Site } \\
\% \text { cover }\end{array}$ & $\begin{array}{c}\text { Shoot } \\
\text { density } \\
\left(\text { no. } 0.25 \mathrm{~m}^{-2} \text { ) }\right.\end{array}$ & $\begin{array}{l}\text { Shoot } \\
\text { height } \\
(\mathrm{m})\end{array}$ & $\begin{array}{l}\text { Vertical } \\
\text { relief } \\
\text { (m) }\end{array}$ & $\begin{array}{c}\text { Bed } \\
\text { perimeter } \\
(\mathrm{m})\end{array}$ & $\begin{array}{c}\text { Bed area } \\
\left(\mathrm{m}^{2}\right)\end{array}$ & $\begin{array}{c}\text { Average } \\
\text { fish density } \\
\left(10 \mathrm{~m}^{-2}\right)\end{array}$ & $\begin{array}{c}\text { Area } \\
\text { sampled } \\
\left(\mathrm{m}^{2}\right)\end{array}$ \\
\hline \multicolumn{8}{|l|}{ Bird Rock } \\
\hline $63 \pm 16$ & $27 \pm 6$ & $1.13 \pm 0.08$ & $0.45 \pm 0.19$ & 68 & 123 & 5.1 & 60 \\
\hline $38 \pm 26$ & $25 \pm 8$ & $1.03 \pm 0.22$ & $0.33 \pm 0.15$ & 42 & 36 & 8.9 & 36 \\
\hline $43 \pm 28$ & $24 \pm 8$ & $1.23 \pm 0.06$ & $0.43 \pm 0.15$ & 29 & 39 & 12.0 & 22 \\
\hline 75 & 19 & 1.10 & 0.10 & 6 & 2 & 3.5 & 2 \\
\hline $40 \pm 26$ & $18 \pm 4$ & $1.18 \pm 0.17$ & $0.05 \pm 0.06$ & 46 & 59 & 7.3 & 40 \\
\hline $71 \pm 21$ & $34 \pm 9$ & $1.21 \pm 0.14$ & $1.58 \pm 0.86$ & 99 & 218 & 11.0 & 90 \\
\hline $65 \pm 17$ & $26 \pm 6$ & $1.21 \pm 0.09$ & $1.31 \pm 0.67$ & 160 & 382 & 6.2 & 150 \\
\hline \multicolumn{8}{|c|}{ La Jolla Caves } \\
\hline $58 \pm 20$ & $35 \pm 17$ & $1.58 \pm 0.31$ & $1.57 \pm 0.59$ & 50 & 60 & 3.2 & 44 \\
\hline $53 \pm 22$ & $36 \pm 10$ & $1.10 \pm 0.13$ & $1.03 \pm 0.96$ & 55 & 66 & 6.1 & 50 \\
\hline $37 \pm 20$ & $15 \pm 4$ & $1.02 \pm 0.37$ & $0.42 \pm 0.39$ & 48 & 37 & 4.1 & 37 \\
\hline $38 \pm 4$ & $26 \pm 11$ & $1.15 \pm 0.07$ & $1.13 \pm 0.53$ & 12 & 5 & 6.7 & 5 \\
\hline $70 \pm 0$ & $32 \pm 9$ & $0.85 \pm 0.07$ & $0.90 \pm 0.42$ & 20 & 7 & 6.3 & 7 \\
\hline $51 \pm 19$ & $26 \pm 12$ & $1.04 \pm 0.15$ & $0.91 \pm 0.46$ & 48 & 63 & 9.7 & 42 \\
\hline \multicolumn{8}{|c|}{ Wipeout Beach } \\
\hline $85 \pm 15$ & $32 \pm 16$ & $1.20 \pm 0.10$ & $1.30 \pm 0.10$ & 20 & 15 & 12.6 & 15 \\
\hline $43 \pm 29$ & $33 \pm 6$ & $1.07 \pm 0.15$ & $2.37 \pm 1.19$ & 36 & 49 & 31.0 & 30 \\
\hline $77 \pm 7$ & $23 \pm 6$ & $1.27 \pm 0.19$ & $1.98 \pm 0.61$ & 104 & 211 & 14.0 & 96 \\
\hline $61 \pm 19$ & $24 \pm 11$ & $1.18 \pm 0.12$ & $1.63 \pm 0.72$ & 66 & 118 & 13.4 & 58 \\
\hline $77 \pm 11$ & $26 \pm 8$ & $1.16 \pm 0.09$ & $2.44 \pm 0.71$ & 86 & 122 & 10.8 & 80 \\
\hline $59 \pm 31$ & $29 \pm 12$ & $1.09 \pm 0.08$ & $2.09 \pm 0.91$ & 109 & 85 & 9.6 & 85 \\
\hline
\end{tabular}

\section{RESULTS}

\section{Characterizing fish assemblages and habitat}

A total of 19 surfgrass beds ranging in size from 2 to $382 \mathrm{~m}^{2}$ were surveyed to estimate habitat attributes (Table 1) and the density of 20 species of fish (Table 2). The cumulative number of species increased as the number of individuals increased (Fig. 2a). To compare species richness, we controlled for variation in bed size by using the estimated species richness on each bed when 25 or 100 individual fish were observed. Estimates of species richness when at least 25 fish were observed excluded 5 surfgrass beds; when at least 100 fish were observed, 12 beds were excluded. For both cases, species richness increased as bed size increased (25 individuals: $r=0.60$, slope $=0.28, \mathrm{p}=0.02$, Fig. 2b; 100 individuals: $\mathrm{r}=0.76$, slope $=0.19, \mathrm{p}=$ 0.05, Fig. 2c).
Table 2. Densities of older juvenile and adult fishes (Adults) and recruits (Recruits) observed in surfgrass beds. Min. size: Minimum sizes of older juvenile and adult fishes used to distinguish recruits from older life stages based on Coyer (1979), DeMartini (1987) and authors' personal observations. TL: total length

\begin{tabular}{|llccc|}
\hline Common name & Taxonomic name & $\begin{array}{c}\text { Min. size } \\
\text { (mm TL) }\end{array}$ & \multicolumn{2}{c|}{$\begin{array}{c}\text { Density } \\
\text { (no. 10 m }{ }^{-2} \text { ) } \\
\text { Adults }\end{array}$} \\
& & & Recruits \\
Senorita & Oxyjulius californica & 100 & 2.99 & 14.24 \\
Blacksmith & Chromis punctipinnis & 100 & 0.41 & 7.40 \\
Giant kelpfish & Heterostichus rostratus & 150 & 0.04 & 3.92 \\
Rock wrasse & Halichoeres semicinctus & 125 & 0.30 & 2.10 \\
Salema & Xenistius californiensis & 100 & - & 1.15 \\
Garibaldi & Hypsypops rubicundus & 125 & 0.30 & 0.80 \\
Kelp bass & Paralabrax clathratus & 100 & 0.24 & 0.50 \\
Kelp perch & Brachyustius frenatus & 75 & 0.16 & 0.19 \\
Shiner perch & Cymatogaster aggregata & 75 & 0.57 & - \\
Walleye perch & Hyperprosopon argenteum & 75 & 0.26 & - \\
Opaleye & Girella nigricans & 175 & 0.23 & - \\
Halfmoon & Medialuna californiensis & 125 & 0.17 & - \\
Sargo & Anisotremus davidsonii & 125 & 0.14 & - \\
Black perch & Embiotoca jacksoni & 100 & 0.12 & - \\
Barred sand bass & Paralabrax nebulifer & 100 & 0.10 & - \\
California sheephead & Semicossyphus pulcher & 100 & 0.08 & - \\
Rainbow perch & Hypsurus caryi & 100 & 0.06 & - \\
Zebraperch & Hermosilla azurea & 175 & 0.04 & - \\
Gray smoothhound & Mustelus californicus & 600 & 0.02 & - \\
Pile perch & Racochilus vacca & 125 & 0.01 & - \\
\hline
\end{tabular}



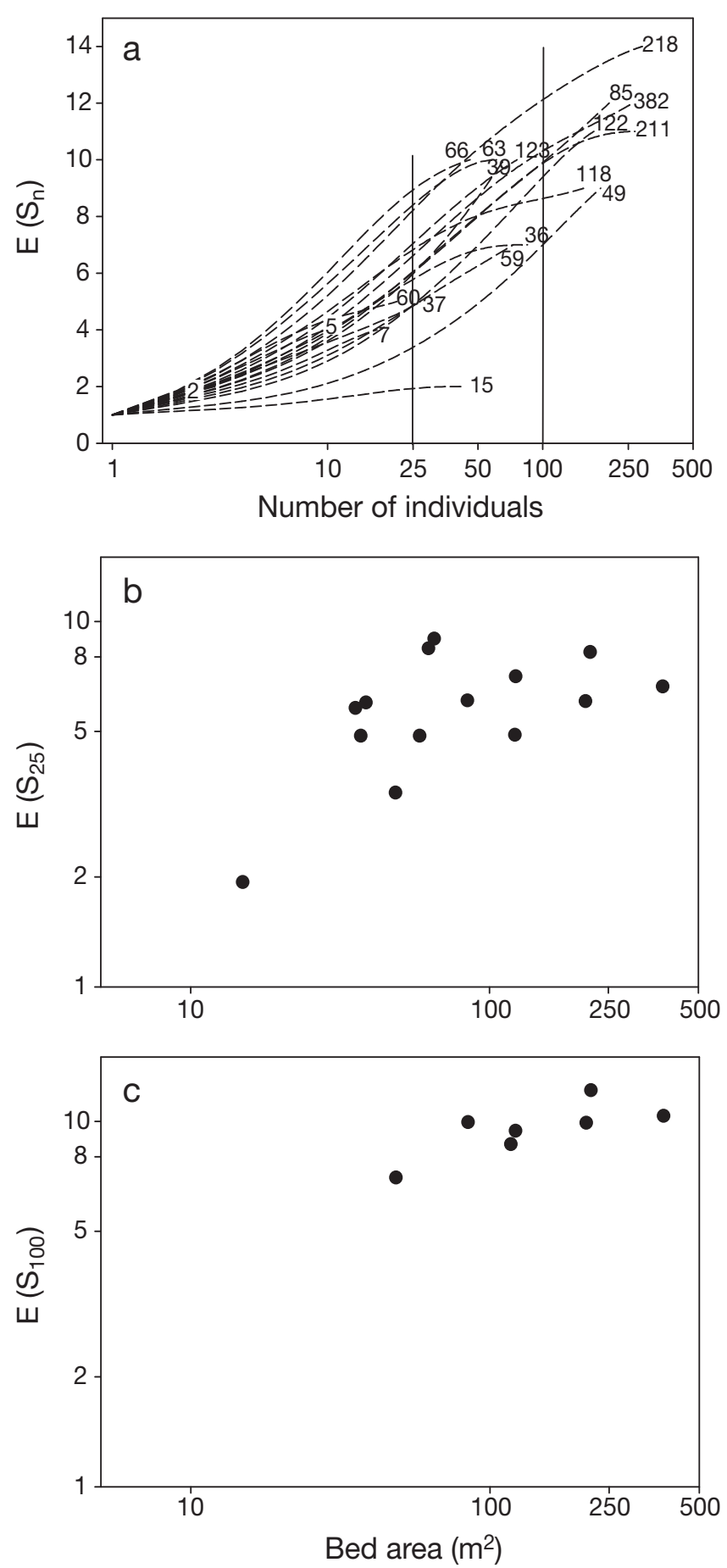

Fig. 2. (a) Rarefaction curves of the total number of older juvenile and adult individuals observed and cumulative number of species for all surfgrass beds surveyed during 2005, $\mathrm{E}\left(\mathrm{S}_{\mathrm{n}}\right)$. Area of the bed is listed next to each rarefaction curve. Solid vertical lines represent the estimated number of species when 25 and 100 individual fish have been observed. (b) Relationship between surfgrass bed area and expected number of species given 25 observed individual fish on surfgrass beds, E $\left(\mathrm{S}_{25}\right)(\mathrm{n}=14)$. (c) Relationship between surfgrass bed area and expected number of species given 100 observed individual fish on surfgrass beds, $E\left(S_{100}\right)(n=7)$
We explored the relationship between the density of older juvenile and adult fishes and habitat attributes on 19 surfgrass beds in 2005, and approximately onethird of the variation in the density of older juvenile and adult fishes was explained by vertical relief only $\left(\mathrm{r}^{2}=0.32, \mathrm{p}=0.01\right)$. Expectedly, relationships between the density of individual species and habitat attributes differed in the amount of variation explained and the importance of habitat attributes in the regression models (Table 3).

We surveyed 9 surfgrass beds for recruit-habitat relationships in 2006. During this year, 3 habitat attributes (percentage cover, shoot density, and vertical relief) were correlated, so we used a PC factor of these variables, which accounted for $75 \%$ of the variation, in all multiple regression models describing recruit fish relationships. Only 2 species, the blacksmith and señorita, were sufficiently abundant to use in multiple regression models. There were no habitat attributes that were retained in the regression model explaining variation in the density of blacksmith, whereas the señorita showed a marginally significant relationship with shoot height (Table 3).

\section{Effects of habitat disturbance on fish density}

Older juvenile and adult fishes showed no response to habitat loss in that their density did not differ significantly between disturbed and unmanipulated reefs (ANCOVA: disturbance treatment, $F_{1,15}=0.82, \mathrm{p}=0.38$; reef area, $F_{1,15}=2.72, \mathrm{p}=0.12$ ), with no significant interaction between treatment and reef area $\left(F_{1,14}=0.21, \mathrm{p}=\right.$ 0.65). Similarly, within disturbed reefs, the density of older juvenile and adult fishes on the half of the reef for which surfgrass had been removed did not differ from the density on the undisturbed half $\left(t_{8}=0.14, \mathrm{p}=0.89\right.$ ), and the density of older juveniles and adults also did not differ when considering only the area of surfgrass (as a covariate) on disturbed and unmanipulated reefs (ANCOVA: disturbance treatment, $F_{1,15}=1.80, \mathrm{p}=0.20$; surfgrass area, $\left.F_{1,15}=2.51, \mathrm{p}=0.13\right)$, with no significant interaction between treatment and surfgrass area $\left(F_{1,14}=\right.$ $0.26, \mathrm{p}=0.62$ ).

Recruit fishes showed a more complex response to habitat loss within surfgrass beds. The density of recruits on the entire surfgrass bed was unaffected by habitat loss (ANCOVA: disturbance treatment, $F_{1,15}=$ $2.11, \mathrm{p}=0.17$; reef area, $F_{1,15}=0.45, \mathrm{p}=0.51$ ), with no significant interaction between treatment and reef area $\left(F_{1,14}=3.67, \mathrm{p}=0.08\right)$. However, when considering only the area covered by surfgrass as a covariate, there was a significant interaction between disturbed and unmanipulated reefs in the density of recruits on surfgrass area only (ANCOVA: treatment $\times$ surfgrass 
Table 3. Backward stepwise multiple regression models of among-bed sources of variation in total density and individual species density of older juvenile and adult $(\mathrm{n}=19)$ and recruit fishes $(\mathrm{n}=9)$ on surfgrass beds. 'Direction of relationship' indicates whether the relationship is positive $(+)$ or negative $(-)$. For taxonomic names see Table 2. NS: not significant

\begin{tabular}{|c|c|c|c|c|c|}
\hline $\begin{array}{l}\text { Independent } \\
\text { variable }\end{array}$ & $\begin{array}{l}\text { Dependent } \\
\text { variable }\end{array}$ & $\begin{array}{l}\text { irection } \\
\text { of } \\
\text { ationship }\end{array}$ & $\begin{array}{l}\text { Partial } \\
\mathrm{r}^{2}\end{array}$ & $\begin{array}{l}\text { Model } \\
\mathrm{r}^{2}\end{array}$ & $\mathrm{p}$-value \\
\hline \multicolumn{6}{|l|}{ Older juv. and adults } \\
\hline Total density & Vertical relief & + & & 0.32 & 0.01 \\
\hline Black surfperch & Bed area & + & & 0.19 & 0.04 \\
\hline California sheephead & Vertical relief & + & & 0.29 & $<0.01$ \\
\hline \multirow[t]{2}{*}{ Garibaldi } & Vertical relief & + & 0.6 & 0.66 & $<0.0001$ \\
\hline & Bed area & + & 0.06 & & \\
\hline \multirow[t]{2}{*}{ Kelp bass } & Bed area & - & 0.38 & 0.42 & $<0.01$ \\
\hline & Percentage cover & $\mathrm{r}-$ & 0.12 & & \\
\hline Rock wrasse & Percentage cover & $r-$ & & 0.38 & $<0.01$ \\
\hline Señorita & Vertical relief & + & & 0.3 & $<0.01$ \\
\hline \multicolumn{6}{|l|}{ Recruits } \\
\hline Total density & & & & & NS \\
\hline Blacksmith & None & & & & \\
\hline Señorita & Shoot height & - & & 0.42 & 0.06 \\
\hline
\end{tabular}

area interaction, $F_{1,14}=5.23, \mathrm{p}=0.04$; Fig. 3). As separate regression analyses of surfgrass area and the density of recruits for each treatment, however, neither relationship was significant (disturbed reefs, $\mathrm{r}^{2}=0.26$, $\mathrm{p}=0.16$; unmanipulated reefs, $\left.\mathrm{r}^{2}=0.29, \mathrm{p}=0.14\right)$.

Within disturbed reefs, the density of total recruits was significantly higher on the undisturbed, vegetated half than the disturbed, rocky half $\left(t_{8}=2.88, \mathrm{p}=0.02\right.$; Fig. 4a). A similar pattern was found for blacksmith $\left(t_{4}=2.96, \mathrm{p}=0.04\right)$, and señorita $\left(t_{8}=3.16, \mathrm{p}=0.01\right)$, but there was no difference in the density of giant kelpfish $\left(t_{3}=2.03, \mathrm{p}=0.14\right.$ ) (Fig. $4 \mathrm{~b}$ to $\left.\mathrm{d}\right)$, and the opposite pattern occurred for rock wrasse, which showed higher densities on the disturbed half of the reefs $\left(t_{6}=-2.81\right.$, $\mathrm{p}=0.03 ;$ Fig. 4e).

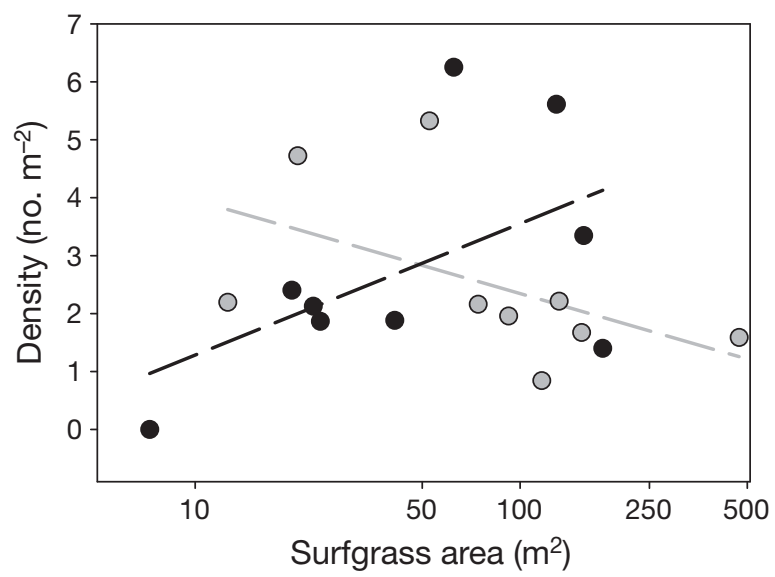

Fig. 3. Densities of recruits in surfgrass only on disturbed (0) and unmanipulated (O) reefs. Dashed lines denote nonsignificant trends in separate regressions for each treatment

\section{DISCUSSION}

\section{Fish-habitat relationships}

To our knowledge, this is the first study to describe the relationships between conspicuous, non-cryptic fishes and habitat attributes of subtidal surfgrass beds and the first to manipulate surfgrass habitat at a scale of entire reefs. In our assessment of species richness among surfgrass beds that varied in size, species richness increased with bed area when standardized to the number of individuals encountered during surveys. In most systems, increasing area alone accounted for about $72 \%$ of the variation in species richness of organisms, but studies of seagrass ecosystems have found opposite results (Neigel 2003). It is interesting that these surfgrass beds conform to the species-area relationship; whether there are fundamental differences between open-coast surfgrass beds and seagrasses in embayments remains to be explored. The relationships we observed here may be of particular use in determining the effects of habitat loss or fragmentation or in evaluating surfgrass beds as essential fish habitat.

Bed area and vertical relief explained the most variation in the density of both recruits and older life stages. Vertical relief or the structure extending upward from the sea floor is a very important factor in driving fish abundance and diversity (Carr 1991, Lowe \& Bray 2006), and it is not surprising that vertical relief is also important in explaining variation in overall and individual species densities in surfgrass beds on rocky benches. It also is not surprising that the factors that explained variation in the density of individual species in surfgrass beds differed in their strength and relative importance among species. Associations between organisms and the habitats in which they reside often are not consistent among species or ecosystems, and many species have different habitat requirements and occur under varying environmental conditions (Bell \& Westoby 1986, Carr 1994, Webster et al. 1998, Sale et al. 2005). The rock wrasse was negatively associated with the percentage cover of surfgrass, and it is more closely associated with rocky or sandy habitats with low-lying algae than in highly vegetated habitats (Lowe \& Bray 2006). Blacksmith are water-column feeders that are not strongly associated with vegetation, so the lack of a significant relationship between their density and habitat characteristics is expected. Señorita exhibited different relationships depending 

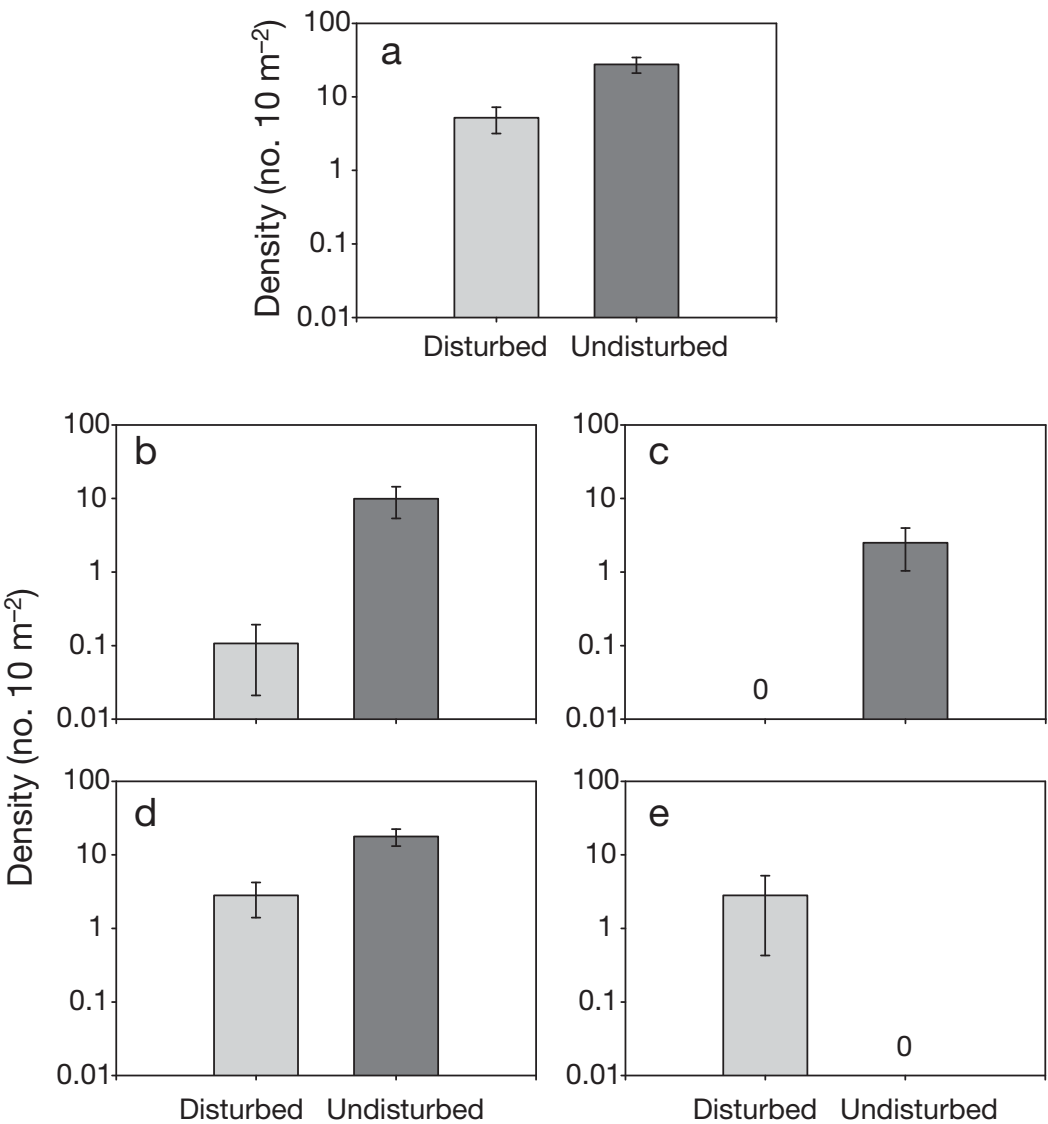

Fig. 4. Densities of recruits in disturbed and undisturbed halves of disturbed surfgrass reefs for (a) total recruits and (b) blacksmith, (c) giant kelpfish,

(d) señorita, and (e) rock wrasse. For taxonomic names see Table 2

1991, Lowe \& Bray 2006). Because of their less restrictive habitat use and much larger sizes relative to recruits, older and larger fishes are able to move among reefs to search for food or more suitable habitat and, thus, may be less affected by habitat loss, at least at this spatial scale. The distribution of these same fishes certainly can be affected by the widespread loss of canopy-forming macroalgae (Ebeling et al. 1985, Graham 2004) that provide considerable habitat structure in the water column above rocky reefs. Surfgrass does not provide this same extent of vertical structure, and its loss may be less important relative to the remaining rocky benches that provide vertical structure and serve as suitable habitat for older juvenile and adult fishes (Stephens et al. 2006). In the absence of hard substrata, however, losses of other seagrasses on unconsolidated bottoms result in a shift in the distribution of fishes, with much lower densities in areas dominated by bare sediment (Bloomfield \& Gillanders 2005, Pihl et al. 2006).

By contrast, responses of recruits to the loss of surfgrass were much stronger and more complex. The interaction in density between disturbance treatment and surfgrass area tended to

on their life stage. For older señorita, vertical relief appeared to be the most important habitat characteristic, and they are often found in groups near macroalgae that provide vertical structure in the water column. Recruit señorita showed an uncharacteristically negative relationship with shoot height, because they are usually found within macroalgae, but they may prefer to position themselves near the benthos next to blades of surfgrass.

\section{Responses of fishes to disturbance}

Although large-scale removal of surfgrass simulates habitat loss from disturbance and a reduction in surfgrass area, the density of older juvenile and adult fishes did not appear to differ in response to this loss. Collectively and by individual species, the density of these fishes did not differ between disturbed and undisturbed halves of the reefs. Older and larger fishes experience much less risk of predation, and they often exhibit an ontogenetic shift in which they may leave the more protective habitats that they use as young recruits (Carr decrease with reef area on unmanipulated reefs and increased with reef area on disturbed reefs; this may be a response to the amount of available surfgrass habitat and the extent of total reef area. As the area of surfgrass on unmanipulated reefs increases to a size over twice that on disturbed reefs, suitable habitat may not be limiting relative to the magnitude of settlement of associated fishes, resulting in lower densities of recruits on large reefs. The densities of recruits on disturbed reefs with only half of the area of surfgrass than that on unmanipulated reefs, however, may be enhanced by the adjacent rocky habitat from which we removed all surfgrass cover. It is also possible that total reef area influences the delivery of settlement-stage larvae by attenuating currents and increasing settlement to the reef, after which recruits that settle to areas of denuded surfgrass may move to more suitable surfgrass habitat. Fishes and invertebrates may decrease in their densities with increasing area of seagrasses, but the opposite pattern also occurs (Eggleston et al. 1998).

In considering only disturbed reefs, it is not surprising that the densities of total recruits and most species 
were higher on the undisturbed halves of reefs because the early life stages of many temperate reef fishes often exhibit close associations with macrophytes (Jenkins et al. 1998, Rooker et al. 1998, Stephens et al. 2006). An exception in our study was the rock wrasse, which was found in higher densities on the disturbed sides of reefs. To our knowledge, there are no data that describe habitat associations and recruitment of rock wrasse, and, based on our observations of this species in understory foliose algae in kelp forests, it is not unusual that young rock wrasse did not positively associate with surfgrass. Whether patterns in recruitment of fishes that we observed here are due to habitat selection or differential mortality of recruits between disturbed and unmanipulated habitats cannot be ascertained because we quantified recruitment weeks to months after settlement occurred.

Disturbance events that impact surfgrass beds and the subsequent recovery of those beds have been studied only at small scales in intertidal zones (Dethier 1984, Menge et al. 2005). Here, habitat disturbance appears to be much more detrimental for recruit than older fishes, likely a result of their stronger and more complex habitat requirements. In consideration of management and conservation efforts, an important issue is the amount of habitat loss that has significant effects on species richness and the density of organisms. Here, we removed $50 \%$ of surfgrass habitat and observed significant decreases in the density of recruit fishes. In comparison, for example, studies of birds and mammals in terrestrial systems suggest that a 70 to $80 \%$ loss of habitat must occur before effects on species richness and density are observed (Andrén 1994). There are obvious differences between marine and terrestrial ecosystems in spatial scale and the habitat requirements of different life stages, and clearly more studies are necessary to assess the role of habitat loss on populations and communities before we more fully understand its effects.

Acknowledgements. We thank the many divers that assisted us in this often harsh environment, especially A. Deza, C. Faist, and M. Gregory. This research was part of the master's thesis of C.J.G., and we thank committee members D. Deutschman and S. Schellenberg for advice and reviewing the manuscript. We also thank S. Hurlbert for valuable advice and discussion, and the California Department of Fish and Game for permission to undertake experiments on the effects of habitat disturbance. Funding was provided by a Blasker-Miah-Rose Environmental Grant from The San Diego Foundation to T.W.A. and by the Edna Bailey Sussman Foundation (through San Diego State University Field Stations), Mabel Myers Memorial Fund, Anchor Environmental LLC., and the San Diego State University Ecology program to C.J.G.

\section{LITERATURE CITED}

Almany GR (2004) Does increased habitat complexity reduce predation and competition in coral reef fish assemblages? Oikos 106:275-284

Anderson TW (2001) Predator responses, prey refuges, and density-dependent mortality of a marine fish. Ecology 82: 245-257

Andrén H (1994) Effects of habitat fragmentation on birds and mammals in landscapes with different proportions of suitable habitat - a review. Oikos 71:355-366

Bell JD, Westoby M (1986) Variation in seagrass height and density over a wide spatial scale - effects on common fish and decapods. J Exp Mar Biol Ecol 104:275-295

Bell SS, Hall MO, Soffian S, Madley K (2002) Assessing the impact of boat propeller scars on fish and shrimp utilizing seagrass beds. Ecol Appl 12:206-217

Bloomfield AL, Gillanders BM (2005) Fish and invertebrate assemblages in seagrass, mangrove, saltmarsh, and nonvegetated habitats. Estuaries 28:63-77

> Bologna PAX, Heck KL (1999) Macrofaunal associations with seagrass epiphytes - relative importance of trophic and structural characteristics. J Exp Mar Biol Ecol 242:21-39

Bostrom C, Jackson EL, Simenstad CA (2006) Seagrass landscapes and their effects on associated fauna: a review. Estuar Coast Shelf Sci 68:383-403

Brown CA, Jackson GA, Holt SA, Holt GJ (2005) Spatial and temporal patterns in modeled particle transport to estuarine habitat with comparisons to larval fish settlement patterns. Estuar Coast Shelf Sci 64:33-46

Bull JS, Reed DC, Holbrook SJ (2004) An experimental evaluation of different methods of restoring Phyllospadix torreyi (surfgrass). Restor Ecol 12:70-79

Caley MJ, Carr MH, Hixon MA, Hughes TP, Jones GP, Menge BA (1996) Recruitment and the local dynamics of open marine populations. Annu Rev Ecol Syst 27:477-500

- Carr MH (1991) Habitat selection and recruitment of an assemblage of temperate zone reef fishes. J Exp Mar Biol Ecol 146:113-137

Carr MH (1994) Effects of macroalgal dymamics on recruitment of a temperate reef fish. Ecology 75:1320-1333

Coyer J (1979) The invertebrate assemblage associated with Macrocystis pyrifera and its utilization as a food source by kelp forest fishes. PhD dissertation, University of Southern California, Los Angeles, CA

Davis GE, Anderson TW (1989) Population estimates of 4 kelp forest fishes and an evaluation of 3 in situ assessment techniques. Bull Mar Sci 44:1138-1151

DeMartini EE (1981) The spring-summer ichthyofauna of surfgrass (Phyllospadix) meadows near San Diego, California. Bull South Calif Acad Sci 80:81-90

DeMartini EE (1987) The effects of operations of the San Onofre nuclear generating station on fish. Report No. 2, Marine Review Committee of the California Coastal Commission, San Francisco, CA

> DeMartini EE, Roberts D (1982) An empirical-test of biases in the rapid visual technique for species-time censuses of reef fish assemblages. Mar Biol 70:129-134

> Dethier MN (1984) Disturbance and recovery in intertidal pools: maintenance of mosaic patterns. Ecol Monogr 54: 99-118

Dexter D (1990) The effect of exposure and seasonality on sandy beach community structure in Portugal. Cienc Biol 10:31-50

Ebeling AW, Laur DR, Rowley RJ (1985) Severe storm disturbances and reversal of community structure in a Southern California kelp forest. Mar Biol 84:287-294 
Eggleston DB, Etherington LL, Elis WE (1998) Organism response to habitat patchiness: species and habitat-dependent recruitment of decapod crustaceans. J Exp Mar Biol Ecol 223:111-132

Exxon Company USA (1993) Final work plan for surfgrass restoration, nearshore construction area, Exxon Santa Ynez Unit pipelines, Report to Santa Barbara County Resource Management Department, Santa Barbara, CA

Fahrig L (2003) Effects of habitat fragmentation on biodiversity. Annu Rev Ecol Evol Syst 34:487-515

> Graham MH (2004) Effects of local deforestation on the diversity and structure of southern California giant kelp forest food webs. Ecosystems 7:341-357

Heck KL, Hays G, Orth RJ (2003) Critical evaluation of the nursery role hypothesis for seagrass meadows. Mar Ecol Prog Ser 253:123-136

Hixon MA, Webster MS (2002) Density dependence in reef fishes: coral-reef populations as model systems. In: Sale PF (ed) Coral reef fishes: dynamics and diversity in a complex ecosystem. Academic Press, San Diego, CA, p 303-325

Holbrook SJ, Reed DC, Hansen K, Blanchette CA (2000) Spatial and temporal patterns of predation on seeds of the surfgrass Phyllospadix torreyi. Mar Biol 136:739-747

Holbrook SJ, Brooks AJ, Schmitt RJ (2002a) Variation in structural attributes of patch-forming corals and in patterns of abundance of associated fishes. Mar Freshw Res 53:1045-1053

Holbrook SJ, Reed DC, Bull JS (2002b) Survival experiments with outplanted seedlings of surfgrass (Phyllospadix torreyi) to enhance establishment on artificial structures. ICES J Mar Sci 59:S350-S355

Hurlbert SH (1971) The nonconcept of species diversity: a critique and alternative parameters. Ecology 52:577-586

Jackson EL, Rowden AA, Attrill MJ, Bossey SJ, Jones MB (2001) The importance of seagrass beds as a habitat for fishery species. Oceanogr Mar Biol 39:269-303

Jenkins GP, Keough MJ, Hamer PA (1998) The contributions of habitat structure and larval supply to broad-scale recruitment variability in a temperate zone, seagrassassociated fish. J Exp Mar Biol Ecol 226:259-278

$>$ Johnson DW (2006) Predation, habitat complexity, and variation in density-dependent mortality of temperate reef fishes. Ecology 87:1179-1188

Laurel BJ, Gregory RS, Brown JA (2003) Predator distribution and habitat patch area determine predation rates on Age-0 juvenile cod Gadus spp. Mar Ecol Prog Ser 251: $245-254$

Lindenmayer DB, Hobbs RJ (2004) Fauna conservation in Australian plantation forests - a review. Biol Conserv

Editorial responsibility: Hans Heinrich Janssen,

Oldendorf/Luhe, Germany
119:151-168

Lowe CG, Bray RN (2006) Movement and activity patterns. In: Allen LG, Pondella DJ, Horn MH (eds) Ecology of marine fishes: California and adjacent waters. University of California Press, Berkeley, CA, p 524-553

Menge BA, Allison GW, Blanchette CA, Farrell TM, Olson AM, Turner TA, van Tamelen P (2005) Stasis or kinesis? Hidden dynamics of a rocky intertidal macrophyte mosaic revealed by a spatially explicit approach. J Exp Mar Biol Ecol 314:3-39

> Moran SM, Jenkins GP, Keough MJ, Hindell JS (2003) Role of physical disturbance in structuring fish assemblages in seagrass beds in Port Phillip Bay, Australia. Mar Ecol Prog Ser 251:127-139

Nagelkerken I, van der Velde G (2004) A comparison of fish communities of subtidal seagrass beds and sandy seabeds in 13 marine embayments of a Caribbean island, based on species, families, size distribution and functional groups. J Sea Res 52:127-147

$>$ Neigel JE (2003) Species-area relationships and marine conservation. Ecol Appl 13:138-145

Pihl L, Baden S, Kautsky N, Ronnback P, Soderqvist T, Troell M, Wennhage H (2006) Shift in fish assemblage structure due to loss of seagrass Zostera marina habitats in Sweden. Estuar Coast Shelf Sci 67:123-132

Rooker JR, Holt GJ, Holt SA (1998) Vulnerability of newly settled red drum (Sciaenops ocellatus) to predatory fish: Is early-life survival enhanced by seagrass meadows? Mar Biol 131:145-151

Sale PF, Danilowicz BS, Doherty PJ, Williams DM (2005) The relation of microhabitat to variation in recruitment of young-of-year coral reef fishes. Bull Mar Sci 76:123-142

Stephens JS, Larson RJ, Pondella DJ (2006) Rocky reefs and kelp beds. In: Allen LG, Pondella DJ, Horn MH (eds) Ecology of marine fishes: California and adjacent waters. University of California Press, Berkeley, CA, p 227-252

Timms BV (1998) Further studies on the saline lakes of the eastern Paroo, inland New South Wales, Australia. Hydrobiologia 381:31-42

> Turner T, Lucas J (1985) Differences and similarities in the community roles of 3 rocky intertidal surfgrasses. J Exp Mar Biol Ecol 89:175-189

- Webster PJ, Rowden AA, Attrill MJ (1998) Effect of shoot density on the infaunal macro-invertebrate community within a Zostera marina seagrass bed. Estuar Coast Shelf Sci 47: 351-357

> Williams SL (1995) Surfgrass (Phyllospadix torreyi) reproduction-reproductive phenology, resource-allocation, and male rarity. Ecology 76:1953-1970

Submitted: April 11, 2007; Accepted: March 25, 2008

Proofs received from author(s): July 30, 2008 